Jurnal Ilmiah Matematika dan Pendidikan Matematika (JMP)

Vol. 9 No. 2, Desember 2017, hal. 87-94

ISSN (Cetak) : 2085-1456; ISSN (Online) : 2550-0422; https://jmpunsoed.com/

\title{
IMPLEMENTASI METODE $B O X$-JENKINS UNTUK MEMPREDIKSI HARGA MINYAK DUNIA DAN PENGARUHNYA TERHADAP HARGA MINYAK INDONESIA
}

\author{
Desty Rakhmawati \\ STMIK AMIKOM PURWOKERTO \\ destyrakhmawati@yahoo.com \\ Eka Tripustikasari \\ STMIK AMIKOM PURWOKERTO
}

\begin{abstract}
Recently Indonesia's oil prices have declined despite oil consumption increases. The decline in Indonesia oil prices is affected by world oil prices. Therefore, the aim of this research is to predict WTI-type world oil price using Box-Jenkins method for non seasonal ARIMA modeling and how big does it influence to Indonesia oil price. WTI world oil price predictions for January to December 2017 are 54.17035, 54.89475, 55.12885 , 55.20406, 55.22817, 55.23590, 55.23837, 55.23916, 55.23942, 55.23950, 55.23953, and 55.23953 dollars per barrels, respectively. Then the magnitude of the effect of WTI world oil prices to Indonesia oil prices is 1.735229 dollars per barrels.
\end{abstract}

Keywords: non seasonal ARIMA, Box-Jenkins method, prediction

\begin{abstract}
ABSTRAK. Akhir-akhir ini harga minyak Indonesia mengalami penurunan meskipun terjadi kenaikan konsumsi minyak. Penurunan harga minyak Indonesia dipengaruhi oleh harga minyak dunia. Oleh karena itu, tujuan penelitian ini adalah memprediksi harga minyak dunia yaitu minyak bumi jenis WTI menggunakan metode Box-Jenkins untuk pemodelan ARIMA non musiman dan seberapa besar pengaruhnya terhadap harga minyak Indonesia. Hasil prediksi harga minyak dunia WTI untuk bulan Januari 2017 sebesar 54,17035 dollar per barel, untuk bulan Februari 2017 sebesar 54,89475 dolar per barel, untuk bulan Maret 2017 sebesar 55,12885 dolar per barel, untuk bulan April sebesar 55, 20406 dolar per barel, untuk bulan Mei sebesar 55,22817 dolar per barel, untuk bulan Juni sebesar 55,23590 dolar per barel, untuk bulan Juli sebesar 55,23837 dolar per barel, untuk bulan Agustus sebesar 55,23916 dolar per barel, untuk bulan September sebesar 55,23942 dolars per barel, untuk bulan Oktober sebesar 55,23950 dollar per barel, untuk bulan November sebesar 55,23953 dolar per barel, untuk bulan Desemberr sebesar 55,23953 dolar per barel. Kemudian besarnya pengaruh harga minyak dunia WTI terhadap harga minyak Indonesia adalah sebesar 1,735229 dolar per barrel
\end{abstract}

Kata Kunci: ARIMA non musiman, metode Box-Jenkins, prediksi

\section{PENDAHULUAN}

Prediksi atau peramalan adalah alat atau teknik yang digunakan untuk memperkirakan kejadian di masa mendatang menggunakan metode tertentu. 
Dalam kehidupan sehari-hari, prediksi dipakai untuk meramalkan cuaca, pertumbuhan ekonomi, ramalan situasi politik, dan dalam penelitian ini, yaitu untuk meramalkan harga minyak dunia. Minyak bumi termasuk dalam sumber daya alam yang tidak dapat diperbaharui. Menurut Widyatmiko (2007), minyak bumi disebut juga crude oil atau minyak mentah. Manfaat utama minyak bumi, menurut Nandi (2006), adalah sebagai sumber tenaga untuk menggerakkan kendaraan. Selain sebagai bahan bakar dan pelumas, minyak bumi juga digunakan dalam berbagai industri seperti pembuatan pelarut, baja serta racun perusak, sabun dan detergen, plastik, bahan peledak, dan lain- lain. Jika melihat begitu besar peranan minyak bumi terhadap kehidupan masyarakat dan seiring dengan peningkatan pertumbuhan penduduk, maka semakin banyak pula konsumsi minyak bumi. Hal ini dapat dilihat dari salah satu penggunaan minyak bumi yaitu penggunaan Bahan Bakar Minyak (BBM) atau yang sering disebut dengan bensin yang meningkat pesat. Kenaikan konsumsi BBM di Indonesia ini tidak diimbangi dengan kenaikan harga BBM. Faktor utama turunnya harga BBM atau harga minyak di Indonesia adalah harga minyak dunia yang menurun. Oleh karena itu, tujuan penelitian ini adalah peramalan harga minyak dunia, yang dapat digunakan untuk mengetahui pengaruh naik turunnya terhadap harga minyak di Indonesia. Harga minyak dunia yang menjadi acuan harga minyak global dan yang akan diramalkan adalah harga minyak jenis West Texas Intermediate (WTI). Prediksi harga minyak dunia WTI ini dilakukan dengan menggunakan metode Box-Jenkins untuk pemodelan ARIMA (Autoregressive Integrated Moving Average) non musiman. Kemudian, manfaat yang diperoleh, peramalan ini dapat digunakan untuk melihat seberapa besar pengaruh harga minyak WTI terhadap harga minyak Indonesia.

\section{METODE PENELITIAN}

Data harga minyak WTI diprediksi dengan menggunakan metode Box Jenkins untuk pemodelan ARIMA non musiman. Langkah-langkah dalam pemodelan ARIMA untuk data harga minyak dunia menurut Rosadi (2011) : 
1. Preprocessing data dan identifikasi model stasioner

Preprocessing data dan identifikasi model stasioner digunakan untuk mengetahui pola data, yaitu pola data harga minyak di dunia, apakah memiliki komponen musiman, trend, dan yang lainnya. Selain itu, langkah ini juga digunakan untuk melihat apakah data tersebut sudah stasioner atau belum. Jika data masih belum stasioner maka data tersebut harus distasionerkan terlebih dahulu dengan transformasi data (transformasi logaritma, atau transformasi Box-Cox). Data yang sudah stasioner dapat dilihat dari bentuk fungsi estimator dari fungsi autokorelasi (sampel ACF), fungsi autokorelasi parsial (sampel PACF), atau unit root terhadap data. Jika data sudah stasioner maka model ARIMA dapat dibentuk berdasarkan sifat dari plot sampel ACF dan PACF.

2. Estimasi Model

Estimasi model yaitu mengestimasi parameter dalam model, seperti koefisien dan nilai variansi dari residual. Untuk melihat koefisien hasil estimasi significant atau tidak, statistik uji $t$ dilakukan dengan asumsi bahwa $H o=0$ dan $H a \neq 0$, derajat bebas $=n-1$ dengan $n$ adalah banyaknya sampel.

3. Diagnostic check dan pemilihan model terbaik

Jika modelnya tepat maka data yang dihitung dengan model (fitted value) akan memiliki sifat- sifat yang mirip dengan data asli, sehingga residual yang dihitung berdasarkan model yang telah diestimasi mengikuti asumsi error dari model teoretis. Seperti sifat white noise, sifat-sifat tersebut dapat dilihat dengan cara melihat plot sampel ACF/ PACF residual yang terstandarisari atau Ljung Box

$$
Q=n(n+2) \sum_{j=1}^{k} \hat{\rho}(j)^{2} /(n-j)
$$

4. Aplikasi model untuk simulasi, peramalan, dan lain- lain

Jika model terbaik sudah diperoleh, maka model tersebut dapat digunakan untuk meramalkan sifat- sifat data di masa yang mendatang. 
Setelah memperoleh hasil prediksi untuk data harga minyak WTI, kemudian analisis pengaruh harga minyak WTI terhadap harga minyak Indonesia dilakukan dengan menggunakan persamaan regresi linear sederhana.

\section{HASIL DAN PEMBAHASAN}

Dari estimasi model atau perkiraan bentuk model ARIMA non musiman berdasarkan hasil dari identifikasi model, diperoleh beberapa alternatif model $\operatorname{ARIMA}(\mathrm{p}, \mathrm{d}, \mathrm{q})$ :

a. Model 1. $\operatorname{AR}(1) \rightarrow y_{t}=0,3203 y_{t-1}+\varepsilon_{t}$

yakni $\log ($ datawti\$World_Oil_Prices) adalah model ARIMA $(1,1,0)$

b. Model 2. $\operatorname{MA}(1) \rightarrow y_{t}=0,2627 y_{t-1}+\varepsilon_{t}$

yakni $\log ($ datawti\$World_Oil_Prices) adalah model ARIMA $(0,1,1)$

c. Model 3. $\operatorname{ARMA}(1,1) \rightarrow y_{t}=0,3924 y_{t-1}-0,0797 y_{t-1}+\varepsilon_{t}$

yakni $\log ($ datawti\$World_Oil_Prices) adalah model ARIMA $(1,1,1)$

d. Model 4. $\operatorname{MA}(2) \rightarrow y_{t}=0,3219 y_{t-1}+0,2271 y_{t-2}+\varepsilon_{t}$

yakni $\log ($ datawti\$World_Oil_Prices) adalah model ARIMA $(0,1,2)$

e. Model 5. $\operatorname{ARMA}(1,2) \rightarrow y_{t}=-0,1439 y_{t-1}+0,4567 y_{t-1}+0,2720 y_{t-2}+\varepsilon_{t}$

yakni $\log ($ datawti\$World_Oil_Prices) adalah model ARIMA $(1,1,2)$

Harga estimasi untuk pengecekan diagnostik bagi model-model yang diamati di atas dapat dilihat dalam tabel berikut.

Tabel 1. Rangkuman Hasil Estimasi

\begin{tabular}{|l|l|l|l|l|l|}
\hline Keterangan & $\begin{array}{l}\text { ARIMA } \\
(1,1,0)\end{array}$ & $\begin{array}{l}\text { ARIMA } \\
(0,1,1)\end{array}$ & $\begin{array}{l}\text { ARIMA } \\
(1,1,1)\end{array}$ & $\begin{array}{l}\text { ARIMA } \\
(0,1,2)\end{array}$ & $\begin{array}{l}\text { ARIMA } \\
(1,1,2)\end{array}$ \\
\hline a1 & 0,3203 & & 0,3924 & & $-0,1439$ \\
\hline & s.e 0,0687 & & s.e. 0,1585 & & s.e. 0,2432 \\
\hline a2 & & & & & \\
\hline b1 & & 0,2627 & $-0,0797$ & 0,3219 & 0,4567 \\
\hline & & s.e. 0,0613 & s.e. 0,1653 & s.e. 0,0717 & s.e. 0,2330 \\
\hline b2 & & & & 0,2271 & 0,2720 \\
\hline & & & & s.e. 0,0780 & s.e. 0,1029 \\
\hline SBC/BIC & $-390,67$ & $-386,76$ & $-385,64$ & $-389,09$ & $-384,14$ \\
\hline
\end{tabular}


Berdasarkan Tabel 1, diperoleh model 1 yaitu model $\operatorname{ARIMA}(1,1,0)$ yang memiliki nilai minimum pada kriteria SBC/ BIC dibandingkan dengan model yang lainnya yang merupakan model terbaik untuk data $\log$ (datawti\$World_Oil_Prices).

Hasil peramalan data harga minyak dunia WTI menggunakan model 1, model ARIMA $(1,1,0)$ dengan model persamaan $y_{t}=0,3203 y_{t-1}+\varepsilon_{t}$ untuk data harga minyak dunia WTI, dapat dilihat pada Tabel 2.

Tabel 2. Hasil Prediksi untuk Data Harga Minyak Dunia WTI

\begin{tabular}{|l|l|}
\hline Periode Prediksi & Prediksi Data \\
\hline Januari 2017 & 54,17035 \\
\hline Februari 2017 & 54,89475 \\
\hline Maret 2017 & 55,12885 \\
\hline April 2017 & 55,20406 \\
\hline Mei 2017 & 55,22817 \\
\hline Juni 2017 & 55,23590 \\
\hline Juli 2017 & 55,23837 \\
\hline Agustus 2017 & 55,23916 \\
\hline September 2017 & 55,23942 \\
\hline Oktober 2017 & 55,23950 \\
\hline November 2017 & 55,23953 \\
\hline Desember 2017 & 55,23953 \\
\hline
\end{tabular}

Tabel 2 di atas menunjukkan hasil ramalan untuk bulan Januari 2017 sampai dengan Desember 2017. Analisis data untuk melihat pengaruh harga minyak dunia WTI terhadap harga minyak Indonesia dilakukan dengan menggunakan analisis regresi. Model estimasi persamaan regresi adalah

Harga minyak indonesia $=0,739401+(0,995828)$ Harga minyak WTI.

Model ini digunakan untuk memprediksi harga minyak Indonesia. Hasil prediksi harga minyak Indonesia selama 12 bulan ke depan dapat dilihat pada Tabel 3 di bawah ini.

Tabel 3. Hasil Prediksi untuk Data Harga Minyak Indonesia

\begin{tabular}{|l|l|}
\hline Periode Prediksi & Prediksi Data \\
\hline Januari 2017 & 54,68373 \\
\hline Februari 2017 & 55,40510 \\
\hline Maret 2017 & 55,63823 \\
\hline April 2017 & 55,71312 \\
\hline
\end{tabular}




\begin{tabular}{|l|l|}
\hline Mei 2017 & 55,73713 \\
\hline Juni 2017 & 55,74483 \\
\hline Juli 2017 & 55,74729 \\
\hline Agustus 2017 & 55,74808 \\
\hline September 2017 & 55,74834 \\
\hline Oktober 2017 & 55,74841 \\
\hline November 2017 & 55,74844 \\
\hline Desember 2017 & 55,74844 \\
\hline
\end{tabular}

Jadi besarnya pengaruh harga minyak dunia WTI terhadap harga minyak Indonesia adalah sebesar 1,735229 dollars per barrels.

\section{KESIMPULAN DAN SARAN}

Berdasarkan pembahasan di atas, dapat diambil kesimpulan bahwa hasil prediksi harga minyak dunia (WTI) untuk bulan Januari 2017 sebesar 54,17035 dollars per barrels, bulan Februari 2017 sebesar 54,89475 dollars per barrels, bulan Maret 2017 sebesar 55,12885 dollars per barrels, bulan April sebesar 55,20406 dollars per barrels, bulan Mei sebesar 55, 22817 dollars per barrels, bulan Juni sebesar 55,23590 dollars per barrels, bulan Juli sebesar 55,23837 dollars per barrels, bulan Agustus sebesar 55,23916 dollars per barrels, bulan September sebesar 55,23942 dollars per barrels, bulan Oktober sebesar 55,23950 dollars per barrels, bulan November sebesar 55,23953 dollars per barrels, dan bulan Desemberr sebesar 55,23953 dollars per barrels. Besarnya pengaruh harga minyak dunia WTI terhadap harga minyak Indonesia adalah sebesar 1,735229 dollars per barrels.

Saran untuk penelitian selanjutnya adalah melakukan prediksi dengan menggunakan data minyak dunia selain jenis WTI.

\section{UCAPAN TERIMAKASIH}

Penulis mengucapkan terima kasih kepada Lembaga Penelitian dan Pengabdian Kepada Masyarakat Kementerian Riset, Teknologi, dan Pendidikan Tinggi yang sudah mendanai penelitian ini. 


\section{DAFTAR PUSTAKA}

Nandi., Handouts Geologi Lingkungan Minyak Bumi dan Gas, Bandung, Fakultas pendidikan ilmu pengetahuan sosial UPI, 2006.

Rosadi, D., Analisis Ekonometrika \& Runtun Waktu Terapan Dengan R, Aplikasi untuk Bidang Ekonomi, Bisnis, dan Keuangan, Yogyakarta, C.V Andi Offset, 2011.

Rosadi, D., Ekonometrika \& Analisis Runtun Waktu Terapan dengan Eviews, Aplikasi untuk Bidang Ekonomi, Bisnis, dan Keuangan, Yogyakarta, C.V Andi Offset, 2012.

Widyatmiko dan Siswani, E. D., Makalah Aspek Manajemen Industri dalam Pabrik Pengilangan Minyak Bumi, Yogyakarta, UNY, 2007. 
